\title{
Cultural Capital, Gender and Intergenerational Educational Mobility in Post-Communist Space
}

\author{
Ausra Maslauskaite $\mathbb{D}$ \\ Department of Sociology, Vytautas Magnus University, 44191 Kaunas, Lithuania; ausra.maslauskaite@vdu.lt
}

check for

updates

Citation: Maslauskaite, A. Cultural

Capital, Gender and

Intergenerational Educational

Mobility in Post- Communist Space.

Societies 2021, 11, 4. https://doi.org/

$10.3390 /$ soc 11010004

Received: 7 October 2020

Accepted: 28 December 2020

Published: 1 January 2021

Publisher's Note: MDPI stays neutral with regard to jurisdictional clai$\mathrm{ms}$ in published maps and institutional affiliations.

Copyright: (C) 2021 by the author. Licensee MDPI, Basel, Switzerland. This article is an open access article distributed under the terms and conditions of the Creative Commons Attribution (CC BY) license (https:// creativecommons.org/licenses/by/ $4.0 /)$.

\begin{abstract}
Post-communist transition in Eastern Europe has affected social stratification and mobility. There is an argument that transition undermined the role of parental cultural capital and increased the importance of parental economic capital in determining the educational mobility of children. In this paper, we examine whether the parental cultural capital has played a role in educational mobility of cohorts born in 1970-1984 and what has been the contribution of the different states of cultural capital. We also consider the gender heterogeneity in the transmission of educational advantage. The study focuses on one country of Eastern Europe-Lithuania, which underwent the transition to a radical neo-liberal form of capitalism. Using data from the Families and Inequalities Survey of 2019, we apply the descriptive and ordinal regression analysis. The results indicate intergenerational educational upward mobility for women. All states of parental cultural capital (objectified, embodied, institutionalized) are relevant for the educational attainment of the transitional cohort. The effects are more pronounced for women, at least in relation to some states of parental cultural capital. On a more general level, the findings imply that the intergenerational reproduction of educational attainment was not substantially altered by the transition, at least during its initial decades.
\end{abstract}

Keywords: cultural capital; gender; educational mobility; post-communist countries; Lithuania

\section{Introduction}

It has been almost three decades since the countries of Central and Eastern Europe started the dramatic transition from socialist authoritarian regime to democracy and market economy. As the first generations of children, whose educational trajectories evolved and reached the final stage during the intensive period of societal changes, have come of age, we ask to what extent their educational attainment has been shaped by the parental cultural capital and how the transmission of educational advantage in the family is related to gender.

Sociological literature is rich in exploring how the parental cultural capital translates into educational advantage in the children's generation. Recent extensive summary of the research on the cultural capital and educational success [1] shows the overall positive effect and the findings are consistent despite the diversity of methodological approaches to measure the cultural capital or the educational outcomes. However, only very few studies consider multiple forms of cultural capital [2]. In addition, the issue of the gendered heterogeneity of the way cultural capital is reproduced in the families only very recently appeared on the research agenda [3,4]. Besides, the existing evidence predominantly covers North American or Western European countries, while cultural reproduction issues in Central and Eastern European countries are very sparsely documented (for the exception, see $[5,6])$.

In this paper, we address the gendered effect of the cultural capital on the final educational attainment of children born in 1970-1984. Our study focuses on one country of Eastern Europe-Lithuania, which in the past three decades, has undergone a transition from socialism to capitalism, which is characterized as a radical neo-liberal form [7]. The cohort under study completed education in the 1990s and early 2000s, thus, during 
the most intense period of the capitalist transition. It was accompanied by a dramatic deterioration of the living standards, rising inequalities, normative chaos, and the restructuring of educational systems. Thus, what was the role of parental cultural resources in social reproduction during the period of societal turmoil? Did economic resources gain importance? Are there gender-specific channels related to how parental cultural resources have contributed to the transmission of educational advantage? We answer these questions based on the representative Families and Inequalities Survey of 2019 by covering the birth cohort of 1970-1984.

Our study contributes to the literature in several ways. First, we consider the multiple forms of cultural capital in the transmission of the educational advantage. Although the cultural capital is often considered in the studies on educational attainment or academic success, most of the studies employ a reductionist approach and examine it partially [2]. Second, there is much research on educational attainment across family structures, but very little studies concerning mechanisms of social reproduction such as parenting style. In this study, we try to bridge this gap by looking at the experienced parenting style as a form of the embodied cultural capital. Third, we examine the gender heterogeneity in the reproduction of social advantage in the families, which is sparsely covered in the literature [4]. Fourth, countries of Central and Eastern Europe are generally absent from the studies on stratification [8] and the existing evidence on the processes of social mobility is far from abundant. Fifth, our research is based on a very recent dataset and gives the opportunity to grasp the social reproduction of the transitional cohort born between 1970 and 1984 whose educational trajectories evolved in an intense period of societal changes.

\subsection{Cultural Capital}

The theoretical framework of the paper is derived from Bourdieu's theory of social reproduction [9], which explains the role of the parental cultural capital in transmission of social advantage and in the social reproduction of the class. Along with the economic and social capital, the cultural capital plays an important role in shaping the life chances of children. In contemporary societies with expanded educational systems, cultural capital becomes a key instrument in passing on the social advantage and in maintaining the social dominance. Parents with higher levels of cultural capital enhance their children's skills, habits, behavior, reasoning and communication strategies and all these factors in turn help children to advance in educational but also in workplace contexts [6,10].

There are three states of cultural capital denoted by Bourdieu: institutionalized, embodied and objectified [11]. An institutionalized state refers to a parent's educational and academic credentials. The objectified state relates to the possession of cultural objects like books, paintings, musical instruments etc. The embodied state refers to "the long lasting dispositions of the mind and the body" [11] (p. 243), which are acquired and accumulated in the lifelong process of socialization.

Although the concept of cultural capital is widely used in research, the operationalization of it is not without shortcomings. Many studies employ a strategy of partial operationalization, leading to the arbitrary selection and empirical testing of one or two states, but claiming to represent the concept in total $[2,12,13]$. In addition, even if there is a wider consensus in the operationalization of the institutionalized and the objectified states, the embodied state of cultural capital is empirically tested employing conceptually diverse indicators. Some focus on the highbrow cultural activities [2]. Others, inspired by Lareau's ideas [10], focus on parenting, patterns of parent-child relationships, communication practices [12], which reflect the broader family environment and internalized skills related to reasoning, language use, psychological dispositions such as autonomy, goal setting and parental support.

According to Lareau [10], middle class parents adopt the cultural logic of concerted cultivation, which is distinct through parent-child discussions, organized activities, and academic engagement. The cultural logic of the concerted cultivation gives the children an 
advantage; it fosters their academic success and thus establishes inequalities already at the early stages of life.

This is evidenced in many studies focusing on school-aged children in Western and Northern Europe and North America [6,12-14]. However, the role of the parental cultural capital for the final educational attainment of the children is covered in the research to a lower extent $[2,15]$.

In this study, we consider multiple forms of cultural capital, thus we examine the institutionalized and objectified states. The embodied state of cultural capital is operationalized as the highbrow cultural activities performed with parents, but also as the parenting practices experienced in childhood.

\subsection{Gender and Cultural Capital}

The transmission of cultural capital is embedded within the dense net of the everyday interactions between children and parents in the family. As family interactions are gendered, one could expect that the transmission of cultural capital, and in turn, the effect of cultural capital on the educational attainment, are shaped by gender. Thus, even if sons and daughters are exposed to the same institutionalized and objectified cultural capital in the parental home, the embodied cultural capital might be mediated through the gender expectations of parents towards their children. Consequently, there could be not only class, but also gender differences in the transmission of the cultural capital. However, as was mentioned, gender is very infrequently considered in the research on social reproduction $[3,8]$.

The sparse evidence suggests that parenting logic related to concerted cultivation is more pronounced in relation to daughters than sons [16-18]. However, other studies prove significant gender differences only in relation to some components of concerted cultivation, for example, school engagement [19]. Why is concerted cultivation parenting more pronounced in relation to girls? Overall, the explanation is linked to the gender identity building process in the family and in the school. Despite the general changes in gender relationships, stereotypical gender identities still have the influence on the expectations parents have towards their children. Boys are viewed as competitive, aggressive, dominating, and girls as conciliatory and cooperative [20]. Thus, boys tend to have more freedom from parental supervisions [21], while daughters are more compliant to parental directives and influence than sons are [22]. In addition, in some contexts, masculinity, at least in young age, embraces resistance to school, hard academic work [20], while the stereotypical notion of femininity supports school work, pro-school orientation [23]. Compliance to masculinity and femininity at least partly explains the gender gap in academic achievement [20]. Girls are more engaged in the outside school structured activities than boys [16]. Gender expectations shape children's out-of-school activities as well: girls are much more involved in organized cultural activities than boys, while the gender gap in sports activities is not as large [19].

Parent-child discussions, which are an important component of concerted cultivation parenting, are also embedded in the psychological dynamics of gendered dyads in the family. Mothers in many families are still the primary caregivers, thus girls in their gender identification process have ongoing relationships with their mothers and develop more affective relationships [24], which in turn might be beneficial for the development of verbal communication skills.

\subsection{Lithuanian Context}

Destratification of the Eastern European societies during the communist period was believed to reduce the educational inequalities and improve opportunities for children from lower socio-economic backgrounds to move upwards [25]. However, there is sound evidence that, in communist societies, parental family background profoundly affects the educational attainment of children and especially the transition to secondary academic or tertiary education $[26,27]$. The expansion of secondary education during the communist 
period secured access to it for almost everyone; yet, the transition to tertiary education remained stratified. Thus, the 'communist affirmative action policies' failed and this is documented for various socialist countries [26,28-31]. Moreover, the role of social origin intensified over the communist period; at least in some countries [27,32].

Several theories explain the persistence of educational inequalities in communist countries. The theory of trajectory maintenance [31] suggests that professionals and administrators possessed correspondingly cultural and social capital and used it to secure the educational credentials of the children and to maintain the social status across generations. Quota policies introduced in the initial stages of the communist period did not eradicate advantages related to social origin. Counterselection theory [28] argues that in the initial stages of the communist rule the quota policies reduced the origin-based inequalities. However, the new cadre class, which emerged and was consolidated in the latter stages of the communist period, used their social connections and other privileges to secure the educational success of their children [28,33]. Kreidl, in his research on Czechoslovakia, proved that both theories 'might be valid in one country with a tracked educational system' [26] (p. 137).

The Lithuanian educational system became part of the Soviet Union system after the second occupation in 1944. It experienced a significant expansion during the communist period [34]. As in other parts of the Soviet Union, the state provided free education, developed the educational infrastructure and supported the ideology of equal educational opportunities. The obligatory lower secondary education of seven grades was introduced in 1949. The general eleven grade secondary education expanded and by the mid-1970s was declared universal [27]. University-educated population grew fastest in the 1960s and 1970s [35]. The first-generation Soviet university graduates were mainly of peasant and working class origin. Pre-war Lithuania's elite were almost totally eradicated due to the political terror, deportations after the Soviet occupation, or due to the forced emigration during or after WWII [36]. Thus, the empty social field in the upper social strata and demand for highly qualified labor force in the period of rapid industrialization created unprecedented opportunities for upward educational mobility. In this period in Lithuania, it might be assumed that the role of cultural capital in final educational attainment was marginal [37].

Proliferation of the secondary education increased the demand for higher education, yet the supply remained more or less stable. Thus, as in other communist countries, family background gained importance in defining the educational opportunities of children [34,38]. Parents focused on the cultural capital, because in the context of small economic inequalities, material wealth was not transmitted to the offspring [32]. Cultural resources of universityeducated parents shaped the children's preferences, taste and dispositions relevant for academic achievement and pursuing a university education. However, enrolment in highly prestigious and competitive university programs was secured by using the social networks to access those in power and paying bribes [39]. Parental financial resources were also used to prepare children for the entry exams and hiring the tutors. Belonging to the elite families secured a place in the special secondary schools [38] and better chances to enter the university. Thus, even if cultural capital was important, social and economic capital were relevant, at least for some educational tracks.

Educational mobility was gender-specific and women outperformed men in the university education already in the late 1980s in Lithuania [40]. The feminization of university education could be related to several developments. The politically motivated compression of earning scales lowered wage returns from education in the Soviet Union [41]. Besides, by the late 1980s, the Soviet economy experienced a decline and the average wages of manual and non-manual work were very similar [42]. This limited the attractiveness of university education for men, who culturally were still seen as being the main breadwinner of the family [43]. Women's choices for university education have been possibly affected by the marriage returns from higher education [44,45], meaning that entry into university increased their chances of marrying a partner with the same educational level and to 
maintain the social status of the family. In addition, for women, higher education secured employment places, which provided opportunities to better balance employment, childcare and household duties. Although the majority of Lithuanian Soviet women were employed, the formal childcare institutions became en masse available only in the late 1970s, but the quality of services were not satisfactory [43]. Professional occupations gave women the opportunity to queue for deficit consumer goods during working hours or establish valuable networks, which secured access to everyday life commodities like clothes, shoes or household appliances unavailable in shops [46].

Transition to market capitalism unleashed manifold inequalities, including the socioeconomic ones [47]. The educational system went through massive changes conditioned by the shortage of resources and low salaries of the educational personnel [48]. In the 1990s, Lithuania, as with the two other Baltic countries, went through very radical and rapid neo-liberal economic reforms. The initial stages of the transition were marked by a dramatic economic decline, de-industrialization, and inflation. However, very rapid market reforms, privatization, and financial policies resulted in macroeconomic stabilization, recovery and spectacular economic growth in the subsequent decade [49].

Some studies show that the intergenerational educational reproduction intensified in the Baltic countries during the post-communist transition [50]. In a recent study, including pooled data from 24 Central and Eastern European countries, Gugushvili [8] argues that parental education played a more salient role in social mobility than the parents' occupation and that the disadvantage of low parental education intensified for transitional cohorts of 1972-1987. Others argue that the role of parents' economic capital for the intergenerational mobility increased in the post-communist period in Central and Eastern Europe [51].

The post-communist transition affected the gender patterns in educational attainment, at least in some countries. For example, Russia in the early 1990s witnessed a decrease in men's enrollment in tertiary education, and this could largely be explained by gender differences in the returns from tertiary education, which increased for women, but not for men [29]. Besides, as some note, the character of the economic reforms in Russia catalyzed the form of capitalism, in which the highest rewards were obtained from trading, speculating, short-term profit making and other economic activities not requiring a university education $[29,42]$.

\subsection{Research Hypotheses}

Based on this theory, existing evidence and context analysis, our study tested several hypotheses:

Hypothesis 1 (H1). Parental cultural capital played a significant role in the educational mobility of the transitional cohort.

Hypothesis 2 (H2). Intergenerational transmission of educational advantage in the transitional cohort is gender-specific and more pronounced for women.

Hypothesis 3 (H3). We expect all three states of cultural capital to be relevant for the educational outcomes of transitional cohort, however, the association between the embodied cultural capital acquired in parental family and the educational outcomes will be more significant for women than men.

\section{Materials and Methods}

Our analysis is based on a Families and Inequalities Survey (www.kartosirseimos. 1t) dataset collected in 2019 in Lithuania. The population of the survey encompasses cohorts born between 1970 and 1984; the sample size is 3000 respondents. Thus, our data cover individuals who at the time of the interview were 35-49 years of age. The representative sample was obtained by using a stratified sampling method. Face-to-face interviews were carried out with respondents in their homes by using a standardized 
questionnaire. The survey recorded a wide range of themes related to the respondents' parental home, life style, partnership and fertility histories, parenting, household, wellbeing and employment conditions.

\subsection{Dependent Variable}

The main dependent variable is the highest level of education attained by the respondent. It was measured on the ISCED 2011 scale; three broad educational groups recoded: university (1), semi-tertiary (2) and secondary or lower education (3). The semi-tertiary group includes education in establishments, which existed prior to 1991 and afterwards was converted into the higher schools and existed till 2000. Depending on the institution, entry requirement was upper or lower secondary education; duration of studies-three to four years. The conversion of higher schools into colleges started in 2000. The last educational category includes the level corresponding to ISCED 0 to 4 . We do not distinguish the category lower than secondary education, because, due to the structural changes in the educational system in the late Soviet period, the share of those without a secondary education is very small.

\subsection{Independent Variables}

A set of variables was used to measure the cultural capital in the respondents' parental home. First, the institutionalized cultural capital was measured by the education of mother or father. The dominance approach [52] was used, which means that if parents had a different level of education, a higher educational category was considered. If one of the parents was absent or no information on the education was provided, the education of the other parent was considered. The cases when respondent spent the childhood with none of the parents were removed. A variable of parental education was recorded into four categories: university, semi-tertiary (see explanation above), secondary, and lower than secondary. This type of education was still widespread in the parents' generation; thus it is distinguished as the individual category. Objectified cultural capital was measured by asking respondent about the number of books in parental home when the respondent was around 15 years of age. The visual presentation of bookshelves was provided to help respondents to answer the question. There were six response categories: 1-"no books", 2 -less than 10 books (half of a shelf) and so on. The last category 6 corresponds to more than 8 shelves, applied to more than 201 books.

Two sets of indicators were used to measure the embodied cultural capital. First, respondents were asked how frequently they attended cultural events with parents until they reached the age of 15 . A frequency response scale was dichotomized: value 1 meaning attended cultural events occasionally or often, 0 -never attended. The second indicator for the embodied cultural capital was 7 items parenting scale. The scale was developed for the purpose of the study (Cronbach's alpha $=0.66$ ). It is self-reported inventory, which retrospectively recodes respondents' experiences in the parental home related to communication patterns, enhancement of child autonomy, parental expectations towards child's education, and parents' engagement in the education process. Response was recorded on the Likert scale ranging from 1-totally disagree to 5-totally agree. The scale includes the following items: 'parents were always interested in my grades', 'parents helped me with the homework, if it was necessary', 'parents encouraged me to study well', 'I confined to parents my concerns and feelings', 'If I behaved badly parents discussed with me my behavior'. Two additional items of the scale were recorded in reverse order: 'parents considered my opinion to a very limited extent'; 'I was punished if I behaved badly'. Following Bodovski's [53] approach, we created the summary index variable. The variable represents the embodied cultural capital related to parent-child relationships, where higher values express more pronounced logic of concerted cultivation. 


\subsection{Control Variables}

Parental social class was included in the analysis and considered as a proxy for the economic capital. Respondents provided information on each of the parents' occupation and employment status when he/she was around 15 years of age. The occupational structure was classified using the Erikson-Goldthrope (EGP) [54] social class scheme. We followed the procedure of Jackson and Evans [55] developed for the analysis of postsocialist societies. Six social classes were identified: I—higher managerial and professional, II-lower managerial and professional, III—routine nonmanual, IV—self-employed (including self-employed farmers, V-manual supervisors and skilled manual, VI-semi and unskilled manual (including farm laborers). They were recorded into three broader categories: salariat (I and II), intermediate class (III, IV, V) and working class (VI). For the measurement of the class of origin, the dominance approach [52] was applied, meaning that in the cases of difference in occupational position the higher level was selected.

Additionally, the analysis includes a variable on gender and birth cohort. We added the control of parental family structure considering the rich evidence on the adverse effect of parental divorce on the educational outcomes of children [56-59]. The survey recorded whether the respondent lived with both parents till the age of 15 or not and whether parents were divorced and what the family structure was (single mother/father, biological parent and step-parent). Two categories were created: childhood in two parents' family (both biological or one biological and one step-parent) or single mother/father family. Respondents raised by grandparents or other relatives were not included in the analysis.

All descriptive statistics are provided in Table 1.

Table 1. Descriptive sample statistics, percentage and means (standard errors).

\begin{tabular}{ccc}
\hline & Column Percent & Means (SE) \\
\hline R's education & & \\
Secondary or lower & 41.9 & \\
Semi-tertiary & 28.2 & \\
University & 29.9 & $3.35(1.21)$ \\
Objectified parental cultural capital & & \\
Book shelves in parental home & & $3.4(0.54)$ \\
Embodied parental cultural capital & 68.0 & \\
Attendance of cultural events (yes) & & \\
Concerted cultivation & & \\
Institutionalized parental cultural capital & 15.6 & \\
Lower than secondary & 31.3 & \\
Secondary & 30.2 & \\
Semi-tertiary & 22.9 & \\
University & & \\
Economic parental capital & 19.3 & \\
Parental social class & 41.2 & \\
Working & 39.6 & \\
Intermediate & 85.6 & \\
Salariat & 59.0 & \\
Two-parent family (yes) & 33.0 & \\
Women & 26.7 & \\
1970-1974 & 40.3 & \\
1975-1979 & 2437 & \\
1980-1984 & & \\
Number & & \\
\hline Sourc: Familis and & & \\
\hline
\end{tabular}

Source: Families and Inequalities Survey, 2019.

We applied descriptive analysis and ordered logistic regression analysis to reveal the predictors of the respondents' educational attainment. Our strategy follows the approach employed by Gugushvili [8]. In all models, the dependent variable is the highest educational attainment of the respondent. As is explained above, we use the ordinal variable 
with three categories. In all models, we also control for the parental family structure in the childhood and birth cohort. The coefficients for the control variables are presented in Appendix A Table A1 and for the interaction terms between cohort and family cultural background variables in Appendix A Table A2. The analysis shown in Table 2 provides descriptive information on the cultural capital in parental home and educational attainment of adult children by gender.

Table 2. Parents' cultural capital and educational attainment of children by gender.

\begin{tabular}{ccccccc}
\hline & \multicolumn{2}{c}{ Secondary or Lower } & \multicolumn{2}{c}{ Semi-Tertiary } & \multicolumn{2}{c}{ University } \\
\cline { 2 - 7 } & Men & Women & Men & Women & Men & Women \\
\hline Book Shelves (Parental Home), Mean & 2.8 & 2.8 & 3.3 & 3.3 & 3.8 & 4.0 \\
Cultural Events (yes), Percentage & 55.1 & 55.2 & 69.8 & 71.8 & 78.7 & 84.6 \\
Concerted Cultivation, Mean & 3.1 & 3.2 & 3.4 & 3.4 & 3.5 & 3.6 \\
\hline
\end{tabular}

Source: Families and Inequalities Survey, 2019.

\section{Results}

\subsection{Descriptive Analysis}

The results illustrate that the possession of books in the parental home in childhood is highest among those with the university education and the trend is not gender-specific. The between-group differences for both gender subsamples are statistically significant (based on ANOVA and post-hoc Scheffe analysis). In addition, the share of those who attended cultural events with parents in childhood is highest among the university-educated, and there is a gradual decline in every lower educational category. The trend is similar for men and women. Talking about concerted cultivation parenting in childhood, mean values are also higher for those with semi-tertiary and university education and lowest for the secondary or lower educated. The trend is very similar for both gender groups, and within each, the between-group differences are statistically significant.

Table 3 presents the intergenerational educational mobility and illustrates the educational attainment of transitional cohort in relation to their parents' education. Descriptive results show a gender-specific pattern. Downward educational mobility is pronounced among men of the 1970-1984 cohort. Almost half of men with university-educated parents (47 percent) did not complete university education, in contrast to 28 percent of women. Moreover, 23 percent of men with university-educated parents, slid down to the bottom of the educational ladder and attained only secondary or lower education, while the share for women with this trajectory is only 7 percent. Thus, the descriptive results reveal that transmission of educational advantage is much stronger for women. The downward mobility pattern of men is also manifest among those with semi-tertiary educated parental family background. In this group, 41 percent of men did not reach the educational level of parents, while among women the share is only 23 percent. In the lowest educational background group (parents with lower than secondary education), 83 percent of men attained secondary education, whereas women with the same origin comprise 60 percent and 40 percent were upwardly mobile.

Table 3. Educational mobility table, birth cohorts 1970-1984.

\begin{tabular}{ccccccc}
\hline & \multicolumn{1}{c}{ Men } & & \multicolumn{2}{c}{ Women } \\
\hline Parents' Education & $\begin{array}{c}\text { Secondary or } \\
\text { Lower }\end{array}$ & Semi-Tertiary & University & $\begin{array}{c}\text { Secondary or } \\
\text { Lower }\end{array}$ & Semi-Tertiary & University \\
\hline lower than secondary & 83 & 12 & 5 & 60 & 25 & 15 \\
secondary & 62 & 22 & 16 & 51 & 29 & 20 \\
semi-tertiary & 41 & 37 & 22 & 23 & 21 & 72 \\
university & 23 & 24 & 53 & 7 & 21 \\
\hline
\end{tabular}




\subsection{Regression Analysis}

In the next step, we applied a series of ordinal logistic regression analyses in order to identify the predictors of adult-children educational attainment. We began with the model, which includes only the variables on the cultural capital. In the next step, we examined the effects of the economic capital on transitional cohort educational outcomes, and in the following, we controlled jointly for the predictors of cultural and economic capital. Guided by our research hypothesis on gendered effect on the cultural capital and educational attainment, in the last model, we included the interaction terms. The goodness-of-fit measures indicate that all models fit the data well. The pseudo- $R^{2}$ also indicates the adequate fit of the models.

Table 4 presents all models of ordinal logistic regression. We started with the testing of our first hypothesis related to the role of the cultural capital for the educational attainment of the transitional cohort (Model 1). We can see that coefficients for all three parental cultural capital states are statistically significant in predicting the educational attainment of transitional cohort adult children. Talking about the objectified state of cultural capital, children exposed to more books in the parental home are more likely to be higher educated. Each additional point on the number of books scale increases the ordered log-odds of being in higher educational category by 0.33 if all other variables in the model are held constant. Respondents who attended cultural events with parents in childhood also have a higher likelihood of being in the higher educational category than individuals who did not have this experience. The second variable on the embodied cultural capital, which is represented by the concerted cultivation cultural logic of parenting, is also positively linked with educational attainment. Each additional point on the concerted cultivation parenting scale will result in a 0.55 unit increase in the ordered log-odds of being in a higher educational category. We also observe the positive association between the institutionalized cultural capital of parents and educational attainment of the transitional cohort. Individuals coming from university and semi-tertiary background families have higher chances of educational attainment compared to ones from a low education family background. In addition, the association of the secondary education family backgrounds is not statistically significant, meaning that chances to advance on the educational ladder are not different from the children with the lowest parental educational background. Thus, we observe that the transmission of educational advantage remained in place for transitional cohort children.

In the next step of the analysis, we added only economic capital variables, which are not of primary interest in this study, but should be considered following the theoretical considerations of the mechanisms of social reproduction and the previously reported results on social mobility in post-communist societies $[8,57]$. The parental economic capital was tested, employing indicators of social class. In Model 2, we can see that individuals coming from salariat and intermediate social class were advantageous in the educational attainment in comparison to the ones with the working-class background. In both cases, the coefficients are positive and statistically significant. Moreover, for the salariat class background, the coefficients are substantially higher than for the intermediate (correspondingly $b=1.94$ and $b=0.61$ ).

Model 3 displays respondents' educational attainment conditional to the parental cultural capital and indicators of economic capital. We observe that all predictors related to the cultural capital remain statistically significant and not substantially altered in size. Thus, more books in the parental home, attendance of cultural events and experienced concerted cultivation logic of parenting increase the chances of higher educational attainment by children of the transitional cohort if we also control for the economic parental capital. Institutionalized cultural capital indicated by parents' education also remains the significant predictor for children's education, proving the advantage of children from university and semi-tertiary family backgrounds. However, after adding to the model the economic capital variables, we see that the effect size decreased. 
Table 4. Respondents' educational attainment conditional to parental cultural and economic capital.

\begin{tabular}{|c|c|c|c|c|c|c|c|c|}
\hline & \multicolumn{2}{|c|}{ Model 1} & \multicolumn{2}{|c|}{ Model 2} & \multicolumn{2}{|c|}{ Model 3} & \multicolumn{2}{|c|}{ Model 4} \\
\hline & $\mathbf{b}$ & SE & $\mathbf{b}$ & SE & $\mathbf{b}$ & SE & & \\
\hline Cultural parental capital & & & & & & & & \\
\hline Books in parental home & $0.33^{* * *}$ & 0.03 & & & $0.34^{* * *}$ & 0.04 & $0.30^{* * *}$ & 0.06 \\
\hline Attendance of cultural events (yes) & $0.20 * * *$ & 0.09 & & & $0.16 *$ & 0.10 & 0.18 & 0.16 \\
\hline Concerted cultivation & $0.55^{* * *}$ & 0.08 & & & $0.58^{* * *}$ & 0.09 & $0.59^{* * *}$ & 0.15 \\
\hline \multicolumn{9}{|l|}{ Parental education (ref. = lower than secondary) } \\
\hline Secondary & 0.21 & 0.13 & & & 0.11 & 0.14 & $0.66^{* *}$ & 0.27 \\
\hline Semi-tertiary & $0.85^{* * *}$ & 0.14 & & & $0.65^{* * *}$ & 0.16 & $0.99^{* * *}$ & 0.28 \\
\hline University & $1.85^{* * *}$ & 0.15 & & & $1.60^{* * *}$ & 0.19 & $1.78^{* * *}$ & 0.31 \\
\hline \multicolumn{9}{|l|}{$\begin{array}{l}\text { Economic parental capital } \\
\text { Parental social class (ref. = working) }\end{array}$} \\
\hline Intermediate & & & $0.61^{* * *}$ & 0.11 & $0.29 * *$ & 0.12 & $0.27^{* *}$ & 0.12 \\
\hline Salariat & & & $1.94^{* * *}$ & 0.11 & $0.41^{* * *}$ & 0.15 & $0.37^{* *}$ & 0.16 \\
\hline Gender (women) & $0.57^{* * *}$ & 0.08 & $0.67^{* * *}$ & 0.07 & $0.58^{* * *}$ & 0.08 & & \\
\hline \multicolumn{9}{|l|}{ Interactions gender ${ }^{*}$ cultural parental capital } \\
\hline Gender * concerted cultivation & & & & & & & -0.10 & 0.19 \\
\hline Gender *attendance of cultural events (yes) & & & & & & & -0.09 & 0.21 \\
\hline Gender * books in parental home & & & & & & & 0.07 & 0.08 \\
\hline Gender* secondary & & & & & & & $0.78^{* *}$ & 0.31 \\
\hline Gender * semi-tertiary & & & & & & & $0.59 *$ & 0.35 \\
\hline Gender * university & & & & & & & 0.22 & 0.35 \\
\hline $\mathrm{N}$ & 2499 & & 2782 & & 2437 & & 2286 & \\
\hline Pseudo $\mathrm{R}^{2}$ (Nagelkerke) & 0.31 & & 0.20 & & 0.32 & & 0.33 & \\
\hline Pseudo $\mathrm{R}^{2}$ (McFadden) & 0.15 & & 0.09 & & 0.15 & & 0.16 & \\
\hline
\end{tabular}

Source: Families and Inequalities Survey, 2019. Notes: ${ }^{* * *} p<0.01,{ }^{* *} p<0.05, * p<0.1$. Models control for birth cohort and childhood family structure; coefficients for these variables are presented in Appendix A Table A1.

Talking about the role of the economic capital for the educational attainment of the transitional cohort, we see that after controlling for the cultural capital, the coefficients decreased. Though the role of the social class background persists, there is a reduction of the size of the coefficients for the intermediate and salariat social class backgrounds. This means that cultural capital variables decrease the explicative power of the economic capital indicators and show the relative importance of cultural capital. Overall, our empirical findings confirm the hypothesis on the role of the parental cultural capital for the educational attainment of the transitional cohort.

The regression analysis mainly corroborates the descriptive findings on the gendered educational mobility of the transitional cohort. In Model 1, we observe the positive coefficients for gender, meaning that women have a higher likelihood of being in the higher educational category compared to men. The gender effect direction is persistent in Model 2 and Model 3 and the effect size has only marginal alterations after we control for parental economic capital and jointly for the cultural and economic capital of the parental family.

Model 4 is dedicated to the testing of the third research hypothesis on the gender differences in the associations between states of cultural capital and educational attainment. In this model, we included the interaction terms between gender and variables on parental cultural capital. Following the research hypothesis, the interaction terms were built setting the reference category to men. Our analysis cannot confirm that the role of the embodied cultural capital (attendance of cultural events and concerted cultivation parenting) on the final educational attainment are moderated by gender. The interaction terms on theses variables are not statistically significant. There is no statistical significance for the interaction between gender and the objectified cultural capital (books in parental home). However, we found the statistically significant association for the gender and the institutionalized parental cultural capital. Women from secondary and semi-tertiary educational backgrounds have a higher likelihood of educational attainment compare to men from same educational family backgrounds. This means that educational family 
background disadvantage to a lower extent shapes the educational attainment of women compared to men. Gender does not moderate the role of university family background for the educational attainment, meaning that educational advantage of this family background is transmitted irrespective of gender.

Lastly, we would like to very briefly discuss the results on the family structure and cohort. Though they are beyond the main interests of this paper, we find the results relevant and interesting. They are presented in Appendix A Tables A1 and A2. Growing up in a twoparent family increases the chances of educational attainment as compared to the single parent family conditional to the economic capital indicators (Table 4, Model 2). We observe the same direction of the association if cultural capital is accounted for, but the statistical significance is low (Table 4, Model 1). However, the effect of parental family structure disappears if one controls for cultural and economic capital jointly. Thus, a disadvantageous effect of growing up in a single parent family on the educational attainment of a transitional cohort seems to be mediated by the cultural capital of the parental family, meaning that cultural capital compensates the economic capital. Regarding the cohort effect, we observe the statistically significant coefficients for the oldest fraction of the transitional cohort, those born in 1970-1974. The negative coefficients indicate that they have lower chances of educational attainment compared to those born in 1980-1984. Our data does not allow us to say whether this result indicates the period effect specific to this birth group or the continuity of the trend, which might also be observed if older birth cohorts are included in the analysis.

Besides, we also examined the interaction terms between the cohort and parental cultural capital (Appendix A Table A2). We cannot prove that the effect of either form of parental cultural capital changed over time, because the interaction terms are not statistically significant.

\section{Discussion}

In this paper, we have attempted to account for the intergenerational educational mobility in post-communist Lithuania. We analyzed the birth cohort of 1970-1984, thus the first generation of children who acquired their educational credentials during the intense period of post-communist transition in the 1990s or early 2000s. Guided by Bourdieu's [9] theory of social reproduction, we asked how the three states of cultural capital acquired in childhood are associated with the final educational attainment of adult children. We also examined the gender heterogeneity in the transmission of educational advantage.

Our first hypothesis implied that parental cultural capital played a significant role in the educational mobility of the transitional cohort. The analysis confirmed this expectation, and our findings are in line with the previous research on the social mobility in the postcommunist period [8]. In contrast to other studies, we consider all three states of cultural capital denoted by Bourdieu [11] and prove the relevance of all in the process of social reproduction under the post-communist transition. Our analysis also proves that even if the role of economic capital for the educational attainment of the transitional cohort was important, the cultural capital played a salient role. On a more general note, these findings prove that the transition to market economy did not alter the role of the cultural capital in the social reproduction. Parental cultural resources, which were documented to be an important factor for the social mobility of children during the communist period [31,32], maintained their significance during the post-communist transformation.

The second hypothesis suggested that the intergenerational transmission of educational advantage is more pronounced for women than men of the transitional cohort. This was largely supported by our findings. In contrast to men, women manifest larger upward educational mobility for all parental family backgrounds. This could be interpreted as the continuity of the pre-transitional pattern of the higher enrollment of women in tertiary education, which began in the 1980s with the stagnation of the Soviet economy and low returns from tertiary education [42]. However, transition to market economy might have intensified this trend. Transition swept away sectors of heavy and light industries [49], 
which previously depended upon places on engineering and technologies programs traditionally dominated by men. In contrast, service sector expanded securing for women the employment opportunities. Thus, gender discrepancies in investments in education might have been catalyzed by uncertain returns from education in the context of a massive restructuring of the economy, discrepancies between labor force supply and demand, and unclear prospects of many professions in the future labor market.

Our third hypothesis suggested that parental cultural capital was significant in determining the educational outcomes of the transitional cohort, but the embodied cultural capital will be more pronounced in relation to woman's education. This hypothesis was not confirmed. Overall, we found that all states of cultural capital (objectified, embodied, institutionalized) are relevant for the educational attainment of the transitional cohort. However, there are no gender differences in how the embodied and objectified states of cultural capital contributes to the educational attainment of the transitional cohort. Gender seems to be important only for the association between the institutional cultural capital and the educational attainment of the transitional cohort. Women appear to be more likely than men to overcome the educational disadvantages related to the parent family and thus to challenge the transmission of disadvantage in their educational paths.

Our study is not without limitations. It is based on the cross-sectional data, thus the intergenerational indicators are recorded as a retrospective information provided by the respondent. The longitudinal data would be beneficial for understanding of the social reproduction in the post-communist transition period, however these types of datasets are unavailable.

Funding: This research was funded by the European Social Fund under a grant agreement with the Research Council of Lithuania (LMTLT) grant number No 09.3.3-LMT-K-712-01-0020.

Informed Consent Statement: Informed consent was obtained from all subjects involved in the survey.

Conflicts of Interest: The author declares no conflict of interest.

\section{Appendix A}

Table A1. Respondent's educational attainment conditional to parents' family structure and cohort.

\begin{tabular}{ccccccc}
\hline & \multicolumn{2}{c}{ Model 1 } & \multicolumn{2}{c}{ Model 2 } & \multicolumn{2}{c}{ Model 3 } \\
\cline { 2 - 7 } & B & SE & b & SE & b & SE \\
\hline Parents' family (not divorced) & $0.21^{*}$ & 0.11 & $0.45^{* * *}$ & 0.10 & $0.23^{*}$ & 0.13 \\
Cohort (ref. = 1980-1984) & & & & & & \\
1970-1974 & $-0.23^{* *}$ & 0.09 & $-0.39 * * *$ & 0.08 & $-0.25^{* * *}$ & 0.07 \\
1975-1979 & 0.15 & 0.09 & -0.12 & 0.09 & 0.02 & 0.10 \\
\hline
\end{tabular}

Source: Families and Inequalities Survey, 2019. Notes: ${ }^{* * *} p<0.01,{ }^{* *} p<0.05,{ }^{*} p<0.1$; models control for cultural (Model 1), economic (Model 2), cultural and economic (Model 3) capitals, all model fitting information is provided in Table 4.

Table A2. Respondent's educational attainment conditional to cohort and parental cultural capital.

\begin{tabular}{ccc}
\hline & \multicolumn{2}{c}{ Model 5 } \\
\cline { 2 - 3 } & b & SE \\
\hline Interactions cohort ${ }^{*}$ cultural parental capital & & \\
$1970-1974$ * concerted cultivation & 0.03 & 0.21 \\
$1975-1979$ * concerted cultivation & 0.01 & 0.22 \\
$1970-1974$ * attendance of cultural events (yes) & -0.33 & 0.14 \\
$1975-1979 *$ attendance of cultural events (yes) & -0.11 & 0.24 \\
$1970-1974 *$ books in parental home & 0.04 & 0.09 \\
$1975-1979 *$ books in parental home & -0.04 & 0.10 \\
\hline
\end{tabular}


Table A2. Cont.

\begin{tabular}{ccc}
\hline & \multicolumn{2}{c}{ Model 5 } \\
\cline { 2 - 3 } & SE & 0.38 \\
$1970-1974 *$ secondary & 0.55 & 0.33 \\
$1970-1974^{*}$ semi-tertiary & 0.13 & 0.37 \\
$1970-1974 *$ university & -0.36 & 0.37 \\
$1975-1979 *$ secondary & 0.66 & 0.38 \\
$1975-1979 *$ semi-tertiary & 0.55 & 0.42 \\
$1975-1979 *$ university & 0.19 & 2437 \\
Pseudo $R^{2}$ (Nagelkerke) & & 0.32 \\
Pseudo $R^{2}$ (McFadden) & 0.15 \\
\hline
\end{tabular}

Source: Families and Inequalities Survey, 2019. Notes: ${ }^{*} p<0.1$. Model controls for all independent and control variables.

\section{References}

1. Jæger, M.M.; Breen, R. A dynamic model of cultural reproduction. Am. J. Sociol. 2016, 121, 1079-1115. [CrossRef] [PubMed]

2. Kraaykamp, G.; Van Eijck, K. The intergenerational reproduction of cultural capital: A threefold perspective. Soc. Forces 2010, 89, 209-231. [CrossRef]

3. Gauthier, A.H. Social class and parental investment in children. In Emerging Trends in the Social and Behavioral Sciences: An Interdisciplinary, Searchable, and Linkable Resource; John Wiley \& Sons: Hoboken, NJ, USA, 2015; Available online: https:// onlinelibrary.wiley.com/doi/abs/10.1002/9781118900772.etrds0306 (accessed on 5 October 2020).

4. Boertien, D.; Bernardi, F. Gendered Diverging Destinies: Changing Family Structures and Inequality of Opportunity among Boys and Girls in the United States. Available online: https:/ / osf.io/preprints/socarxiv/c3mpx/ (accessed on 5 October 2020).

5. Flere, S.; Krajnc, M.T.; Klanjšek, R.; Musil, B.; Kirbiš, A. Cultural capital and intellectual ability as predictors of scholastic achievement: A study of Slovenian secondary school students. Br. J. Sociol. Educ. 2010, 31, 47-58. [CrossRef]

6. Bodovski, K.; Jeon, H.; Byun, S.Y. Cultural capital and academic achievement in post-socialist Eastern Europe. Br. J. Sociol. Educ. 2017, 38, 887-907. [CrossRef]

7. Bohle, D.; Greskovits, B. Capitalist Diversity on Europe's Periphery; Cornell University Press: Ithaca, NY, USA, 2012.

8. Gugushvili, A. Change or continuity? Intergenerational social mobility and post-communist transition. Res. Soc. Stratif. Mobil. 2017, 52, 59-71. [CrossRef]

9. Bourdieu, P. Distinction: A Social Critique of the Judgement of Taste; Harvard University Press: Cambridge, MA, USA, 1984.

10. Lareau, A. Unequal Childhoods: Class, Race, and Family Life; University of California Press: Los Angeles, CA, USA, 2003.

11. Bourdieu, P. Forms of capital. In The Sociology of Economic Life, 3rd ed.; Granovetter, M., Swedberg, M., Eds.; Routledge: New York, NY, USA, 2018; pp. 145-161.

12. Tramonte, L.; Willms, J. Cultural capital and its effects on education outcomes. Econ. Educ. Rev. 2010, 29, 200-213. [CrossRef]

13. Andersen, P.L.; Hansen, M.N. Class and Cultural Capital-The Case of Class Inequality in Educational Performance. Eur. Sociol. Rev. 2012, 28, 607-621. [CrossRef]

14. Brooks-Gunn, J.; Klebanov, P.K.; Duncan, G.J. Ethnic differences in children's intelligence test scores: Role of economic deprivation, home environment, and maternal characteristics. Child Dev. 1996, 67, 396-408. [CrossRef]

15. Marks, G.N. The influence of cultural capital on educational and early labour market outcomes of young people in Australia. In Quantifying Theory: Pierre Bourdieu; Robson, K., Sanders, C., Eds.; Springer: Cham, Switzerland, 2009; pp. 89-103.

16. Fletcher, A.C.; Nickerson, P.; Wright, K.L. Structured leisure activities in middle childhood: Links to well-being. J. Community Psychol. 2003, 31, 641-659. [CrossRef]

17. Cheadle, J.E.; Amato, P.R. A quantitative assessment of Lareau's qualitative conclusions about class, race, and parenting. J. Fam. Issues 2011, 32, 679-706. [CrossRef]

18. Warner, C.H.; Milkie, M.A. Cultivating gendered talents? The intersection of race, class, and gender in the concerted cultivation of US Elementary Students. In Notions of Family: Intersectional Perspectives Advances in Gender Research; Kohlman, M.H., Krieg, D.B., Dickerson, J.B., Eds.; Emerald: Bingley, UK, 2013; Volume 17, pp. 1-27.

19. McCoy, S.; Byrne, D.; Banks, J. Too much of a good thing? Gender,'concerted cultivation'and unequal achievement in primary education. Child Indic. Res. 2012, 5, 155-178. [CrossRef]

20. Francis, B.; Skelton, C. Reassessing Gender and Achievement: Questioning Contemporary Key Debates; Routledge: Abingdon, UK, 2005.

21. Posner, J.K.; Vandell, D.L. After-school activities and the development of low-income urban children: A longitudinal study. Dev. Psychol. 1999, 35, 868-879. [CrossRef] [PubMed]

22. Power, T.G.; McGrath, M.P.; Hughes, S.O.; Manire, S.H. Compliance and self-assertion: Young children's responses to mothers versus fathers. Dev. Psychol. 1994, 30, 980-989. [CrossRef]

23. Legewie, J.; DiPrete, T.A. School context and the gender gap in educational achievement. Am. Sociol. Rev. 2012, 77, 463-485. [CrossRef]

24. Chodorow, N. Mothering, object-relations, and the female oedipal configuration. Fem. Stud. 1978, 4, 137-158. [CrossRef] 
25. Ganzeboom, H.B.; De Graaf, P.M.; Robert, P. Reproduction theory on socialist ground: Intergenerational transmission of inequalities in Hungary. In Comparative Studies of Mobility and Attainment; Kallenberg, A.L., Ed.; JAI Press: Greenwich, CT, USA, 1990; pp. 79-104.

26. Kreidl, M. Politics and secondary school tracking in socialist Czechoslovakia, 1948-1989. Eur. Sociol. Rev. 2004, 20, 123-139. [CrossRef]

27. Gerber, T.; Hout, M. Educational stratification in Russia during the Soviet Period. Am. J. Sociol. 1995, 101, 611-660. [CrossRef]

28. Matějů, P. Who won and who lost in a socialist redistribution in Czechoslovakia? In Persistent Inequality: Changing Educational Attainment in Thirteen Countries; Shavit, J., Blossfeld, H.-P., Eds.; Westview Press: Boulder, CO, USA, 1993; pp. $251-271$.

29. Gerber, T. Educational Stratification in Contemporary Russia: Stability and change in the face of economic and institutional crisis. Soc. Educ. 2000, 73, 219-246. [CrossRef]

30. Heyns, B.; Bialecki, I. Educational inequalities in postwar Poland. In Persistent Inequality: Changing Educational Attainment in Thirteen Countries; Shavit, J., Blossfeld, H.-P., Eds.; Westview Press: Boulder, CO, USA, 1993; pp. 303-335.

31. Henley, E.; McKeever, M. The persistence of educational inequalities in state-socialist Hungary: Trajectory-maintenance versus counterselection. Sociol. Educ. 1997, 70, 1-18. [CrossRef]

32. Kraaykamp, G.; Nieuwbeerta, P. Parental background and lifestyle differentiation in Eastern Europe: Social, political, and cultural intergenerational transmission in five former socialist societies. Soc. Sci. Res. 2000, 29, 92-122. [CrossRef]

33. Matějů, P.; Peschar, J.L. Family background and educational attainment in Czechoslovakia and the Netherlands. Int. J. Sociol. 1989, 19, 72-103. [CrossRef]

34. Hernes, G.; Knudsen, K. The iron law of inequality: Different paths, but same results? Some comparisons between Lithuania and Norway. Eur. Sociol. Rev. 1991, 7, 195-211. [CrossRef]

35. Stumbrys, D. Gyventojų išsilavinimo kaita. In Lietuvos Demografinè Kaita; Stankūnienè, V., Baublytè, M., Žibas, K., Stumbrys, D., Eds.; Vytauto Didžiojo Universitetas: Kaunas, Lietuva, 2016; pp. 49-77.

36. Misiunas, R.J.; Taagepera, R. The Baltic States: Years of Dependence, 1940-1980; University of California Press: Los Angeles, CA, USA, 1983.

37. Tomusk, V. When East meets West: Decontextualizing the quality of East European higher education. Qual. High. Educ. 2000, 6, 175-185. [CrossRef]

38. Konstantinovskiy, D.L. Social inequality and access to higher education in Russia. Eur. J. Educ. 2012, 47, 9-24. [CrossRef]

39. Leonavičius, V.; Rutkienè, A. Aukštojo Mokslo Sociologija; Vytauto Didžiojo Universitetas: Kaunas, Lithuania, 2010.

40. Ambrozaitienè, D.; Stankūnienè, V.; Maslauskaitė, A.; Balandienè, R. (Eds.) Lietuvos Gyventojai: Struktūra ir Demografinè Raida; Lietuvos Statistikos Departamentas: Vilnius, Lietuva, 2006.

41. Veraschagina, A. Education and socioeconomic mobility in post-communist countries. In Social Exclusion; Parodi, G., Sciulli, D., Eds.; Springer: Berlin/Heidelberg, Germany, 2012; pp. 67-91.

42. Gerber, T.; Hout, M. More shock than therapy: Market transition, employment, and income in Russia, 1991-1995. Am. J. Sociol. 1998, 104, 1-50. [CrossRef]

43. Leinarte, D. Adopting and Remembering Soviet Reality: Life Stories of Lithuanian Women, 1945-1970; Brill Rodopi: Leiden, The Netherlands, 2010.

44. Oppenheimer, V.K. A theory of marriage timing. Am. J. Sociol. 1988, 94, 563-591. [CrossRef]

45. Buchmann, C.; DiPrete, T.A. The growing female advantage in college completion: The role of family background and academic achievement. Am. Sociol. Rev. 2006, 71, 515-541. [CrossRef]

46. Žiliukaite, R. Ekonominis "nepaklusnumas"? Blatas ir kitos neformalios ekonominès praktikos. In Nematoma Sovietmečio Visuomene; Ramonaitè, A., Ed.; Naujasis Židinys-Aidai: Vilnius, Lithuania, 2015; pp. 128-153.

47. Heyns, B. Emerging inequalities in central and Eastern Europe. Annu. Rev. Sociol. 2005, 31, 163-197. [CrossRef]

48. Review of National Policies for Education: Lithuania 2002. Available online: https://www.oecd-ilibrary.org/education/reviewsof-national-policies-for-education-lithuania-2002_9789264193475-en (accessed on 5 October 2020).

49. Norkus, Z. Du Nepriklausomybès Dvidešimtmečiai. Kapitalizmas, Klasès ir Demokratija Pirmojoje ir Antrojoje Lietuvos Respublikoje Lyginamosios Istorinès Sociologijos Požiūriu; Aukso žuvys: Vilnius, Lietuva, 2014.

50. Hazans, M.; Trapeznikova, I.; Rastrigina, O. Ethnic and parental effects on schooling outcomes before and during the transition: Evidence from the Baltic countries. J. Popul. Econ. 2008, 21, 719-749. [CrossRef]

51. Lippényi, Z.; Gerber, T.P. Inter-generational micro-class mobility during and after socialism: The power, education, autonomy, capital, and horizontal (PEACH) model in Hungary. Soc. Sci. Res. 2016, 58, 80-103. [CrossRef]

52. Erikson, R. Social class of men, women and families. Sociology 1984, 18, 500-514. [CrossRef]

53. Bodovski, K. Parental practices and educational achievement: Social class, race, and habitus. Br. J. Sociol. 2010, 31, 139-156. [CrossRef]

54. Erikson, R.; Goldthorpe, J.H.; Portocarero, L. Intergenerational class mobility in three Western European societies: England, France and Sweden. Br. J. Sociol. 1979, 30, 415-441. [CrossRef]

55. Jackson, M.V.; Evans, G. Rebuilding walls: Market transition and social mobility in the post-socialist societies of Europe. Sociol. Sci. 2017, 4, 54-79. [CrossRef]

56. Kreidl, M.; Štípková, M.; Hubatková, B. Parental separation and children's education in a comparative perspective: Does the burden disappear when separation is more common? Demogr. Res. 2017, 36, 73-110. [CrossRef]

57. Bernardi, F.; Boertien, D. Understanding heterogeneity in the effects of parental separation on educational attainment in Britain: Do children from lower educational backgrounds have less to lose? Eur. Sociol. Rev. 2016, 32, 807-819. [CrossRef] 
58. Boertien, D.; Bernardi, F.; Härkönen, J. Family Structure and Socioeconomic Inequality of Opportunity in Europe and the United States. In Unequal Family Lives. Causes and Consequences in Europe and the Americas; Cahn, N., Carbone, L., DeRose, F., Wilcox, W.B., Eds.; Cambridge UP: Cambridge, UK, 2018; pp. 165-178.

59. Havermans, N.; Swicegood, G.; Matthijs, K. Floor Effects or Compensation of Social Origin? The Relation between Divorce and Children's School Engagement According to Parents' Educational Level. In Divorce in Europe; Mortelmans, D., Ed.; Springer: Cham, Switzerland, 2020; pp. 355-370. 